\title{
SATISFACTION AND LOYALTY IN B2B RELATIONSHIPS IN THE FREIGHT FORWARDING INDUSTRY: ADDING PERCEIVED VALUE AND SERVICE QUALITY INTO EQUATION
}

\author{
Irene GIL-SAURA*, Gloria BERENGUER-CONTRI, María Eugenia RUIZ-MOLINA \\ Dept of Marketing, University of Valencia, Valencia, Spain
}

Received 22 June 2018; revised 22 September 2018; accepted 21 October 2018

\begin{abstract}
This paper focuses on analysing the determinants of satisfaction (service quality, perceived value), as well as its possible influence on customer loyalty of freight forwarders to freight transport service providers (by road/maritime/air) in Spain. To this end, we propose a causal model tested using information from 205 freight forwarders collected through personal interviews. The model was estimated using the Partial Least Squares (PLS) approach. Moreover, the existence of differences in the perceptions on the analysed variables between transport modes is tested through ANOVA. Results show that service quality has an influence on customer satisfaction, both directly, as well as through perceived value. In turn, it is confirmed the relationship between satisfaction with the transportation company and customer loyalty. Furthermore, there are significant differences in quality dimensions and satisfaction between transport modes. This study confirms the importance of service quality and perceived value to promote the link between chain actors: freight forwarder and transport service provider. The main aim of this research is to go deeper into the study of satisfaction and loyalty of freight forwarders to freight transport service providers. Findings provide evidence about differences in the dimensionality of service quality between B2C and B2B settings and, even in the latter, differences between freight forwarding services and other industries are observed. The present paper is one of the few studies that obtains relevant information about several transport modes simultaneously and the findings reinforce the notion that perceptive processes in each of them are different.
\end{abstract}

Keywords: B2B loyalty, service quality, perceived value, goods transportation, freight forwarder, carrier.

\section{Introduction}

For many years, logistics and, specifically, goods transportation, were considered as an ancillary activity to business management. However, physical distribution has been recognized as vital to the economy of firms and countries (Singh et al. 2018), and as a crucial link in the competitiveness of supply chains (Lagoudis et al. 2006). Thus, increased competition has become a catalyst for the development of new long term oriented relationships between companies, built on pillars such as trust, commitment, satisfaction, and loyalty. In this context service excellence is considered one of the main objectives of the strategy of the companies providing logistics services, such as transport service providers, freight forwarders, shippers and consignees, ports, airports, cargo airlines, etc. (Singh et al. 2018).

In the services marketing literature, it is recognized that satisfaction is a good indicator, if not the best, of future firm profits. In the same vein, an extensive amount of research and empirical evidence refers to the connection between high service quality and firm success (e.g. Yuen, Thai 2015; Parasuraman et al. 1994) and argues that high customer satisfaction is related to increased loyalty (e.g. Chang, Thai 2016; Bardauskaite 2014). The literature review shows that most of the studies on this topic have focused on consumers and, comparatively, the contributions in the B2B setting are relatively few in number (Watson et al. 2015). To build bridges between the $\mathrm{B} 2 \mathrm{C}$ and $\mathrm{B} 2 \mathrm{~B}$ domains of academic research, often divided, and having identified different contributions that place the B2B setting as an area of critical interest (Bucklin 2015), we focus on relationships between companies. Regarding goods transportation, research on the formation of variables such as service quality and satisfaction, as well as their consequents, is not conclusive (Kersten, Koch 2010). Notwithstanding, there are studies that raise service perceptions as one of the most persuasive variables for mode and

*Corresponding author. E-mail: irene.gil@uv.es 
carrier selection (Solakivi, Ojala 2017). In this sense, the literature has identified the discrepancy between shippers' and carriers' perceptions regarding the service variables involved in carrier selection. Likewise, it has also been identified the tendency of logistics companies to develop relationships with customers and suppliers with the aim of increasing the levels of satisfaction and loyalty (Daugherty 2011).

Since the early 2016, the container shipping market experiences a recession in terms of the freight rates (Chen et al. 2017). In this context, all parties in the logistic chain are affected and, more importantly, freight forwarders suffer from the price-cutting programs since they organize shipments for companies and act as experts in logistics for a profit based on the shipping cost (Chen et al. 2009). Since carriers and freight forwarders face such similar challenges (Chen et al. 2017), we find interest in analysing freight forwarders' perceptions on the service quality and perceived value delivered by their main carrier, and how both variables may influence satisfaction and loyalty. Even if these constructs have been analysed in the services literature in the context of $\mathrm{B} 2 \mathrm{~B}$ relations, there is little previous research on customer satisfaction and retention in the field of freight forwarder management.

In this context, the main aim of this research is to go deeper into the study of satisfaction and loyalty of freight forwarders to freight transport service providers, focusing on the relationships between freight forwarders and their main carriers in the different modes of transport (road, sea and air). To achieve this goal we estimate a causal model, providing evidence about how service quality and perceived value, are key elements in explaining customer satisfaction (Yuen, Thai 2015; Mahmud et al. 2013) and ultimately, customer loyalty, in view of the critical importance of retention for the competitiveness of logistics companies in the current complex context (Chang, Thai 2016).

\section{Theoretical framework}

\subsection{Satisfaction in goods transportation}

Since the late sixties, satisfaction has been a frequently studied topic by marketing researchers. In the context of the relation between services companies, many of them have developed initiatives addressed to enhance customer satisfaction and perceived value through loyalty programs to ensure long-term customer engagement, since satisfied customers are more likely to stay with the company, increase their expenditure and tell others about their positive experiences (Naumann et al. 2009).

Notwithstanding, in the B2B setting, whereas some studies have found a strong positive relationship between satisfaction and loyalty intentions and behaviours, others argue that many satisfied customers are not loyal and will switch suppliers (Kumar et al. 2013). These mixed results may allow to infer that loyalty towards service providers might depend on other type of variables, specific to each industry, and the evaluation of customer satisfaction may be assisted by data on customer perceptions about the trade-off benefits and costs - beyond price - that can determine long-term relations between companies.

However, there is less tradition in the study of satisfaction, its antecedents and its consequents in the context of goods transportation in contrast to passenger transportation (e.g. Mahmud et al. 2013). Moreover, most contributions focus on goods transportation by sea (Yuen, Thai 2017, 2015; Chang, Thai 2016; Wong et al. 2008; Ugboma et al. 2007; Lu 2003; Durvasula et al. 2000) and international logistics services without reference to a specific mode of transport (Chen, Lee 2008). This research gap has motivated our interest in comparing different transport modes.

Moreover, research in this area intends to identify internal and external factors that contribute to satisfaction (Wong et al. 2008), to measure customer satisfaction (Ugboma et al. 2007), to assess the relationship between the methods of service recovery and satisfaction (Durvasula et al. 2000) and the influence of satisfaction on loyalty to service providers of international logistics (Chen, Lee 2008). In this line, Durvasula et al. (2000) find empirical support to the notion that customer satisfaction is affected by both customer perceptions of service encounters and perceived service quality, thus highlighting the important role played by customer service personnel in generating satisfaction in goods transportation. Lu (2003) concluded that satisfaction is an antecedent of shipper-carrier relationships. Additionally, Wong et al. (2008) point out the contribution to customer satisfaction of the following factors: shippers' own capabilities, comprehensive global service, cargo handling capabilities, cargo location, shipper' reputation, customer service and relationship with the customs office. More recently, Yuen and Thai (2015) identify the dimensions of service quality in liner shipping and examine their effects on customer satisfaction in 183 liner shippers in Singapore, concluding that service differentiation by time-related attributes results in greater customer satisfaction than practising cost leadership. Following this research line, Yuen and Thai (2017) argue that shippers' satisfaction derived from the appraisal of a service quality attribute is moderated by the perceived performance of other service quality attributes. The relationship between service quality and satisfaction has been confirmed in port services (Ugboma et al. 2007; Chang, Thai 2016).

Leaving aside maritime transportation, Cook et al. (1999) found that satisfaction is higher in transportation by road in comparison to rail. Later, it has been concluded that firm satisfaction with the services delivered by International Logistics Service Providers (ILSP) is an antecedent of customer loyalty (Chen, Lee 2008).

From the methodological perspective, in the measurement of satisfaction, there are two main positions: (1) measuring overall satisfaction through a single item (Park et al. 2004; Petrick 2004) or a reduced number of items (Yuen, Thai 2017; Ugboma et al. 2007; Chen, Lee 2008), and (2) through various service attributes (Chang, Thai 2016; Lu 2003; Wong et al. 2008). 


\subsection{Antecedents of satisfaction: service quality and perceived value}

\subsubsection{Service quality in goods transportation}

Service quality has been traditionally related to several outcome variables. Flodén et al. (2017) identify studies that have considered service quality as a key factor in transport service or mode of transport. Moreover, the importance of service quality on satisfaction has been highlighted in several studies in the context of B2B relations and in services (Huang et al. 2017), since it is the only construct in the satisfaction-profit chain where service firms have control over their performance. Studies on this relationship have been conducted at the global level (i.e. estimating the aggregated effect of service quality on customer satisfaction) or the attribute level (i.e. estimating the effect of each service quality attribute on customer satisfaction (Yuen, Thai 2017)), since service quality is one of the most influential elements in the choice of transport, highlighting the superiority of certain attributes over price (Whyte 1993).

The literature on service quality attributes has identified that transit time, damage and loss of goods are critical dimensions in the choice of intermodal goods transport (Harper, Evers 1993). Among the works evaluating service quality as a multidimensional variable, Ludvigsen (1999) identifies four dimensions (operational excellence, availability, load risk and technical efficiency), Cook et al. (1999) point to three quality dimensions (reliability, availability and transit time), Lu (2003) proposes four factors (timing, price, storage and sales), and finally, Bergantino and Bolis (2008) identify service frequency and transit time as the most influential variables in the transport mode decision.

In addition, in goods transport by sea, Lu (2007) uses service quality to identify freight forwarders' capacities and key resources, obtaining three key quality factors for resources (equipment, information equipment and corporate image) and 7 key factors for abilities (purchases, operations, human resource management, customer service, integrated information, price and financial management). Similarly, Thai (2008) studies service quality in the maritime transport of goods on a 24-item scale grouped in ROPMIS model with 6 dimensions (Resources-OutcomesProcess-Management-Image-Social responsibility).

Lobo (2010) analysed shippers' evaluations of the various service delivery components of their most preferred shipping line. Quality was assessed through perceptions about performance in subservices delivered by shipping companies: sales and marketing; telephone services; personal visits to the shipping line office; booking services; documentation; claims and operations, showing that the latter contributed directly to overall customer satisfaction.

In the context of ocean freight transport, Ding and Tsai (2012) assessed the quality improvement of service recovery for ocean freight forwarders in Taiwan, concluding that freight cost, compensation for cargo damages and accuracy of shipping schedule are the three most important criteria of service quality.
In the freight forward business, Huang et al. (2015) considered instant response, tailor-made service and schedule reliability as quality criteria; while Song et al. (2015) proposed service quality as a key performance indicator of container shipping companies with the inclusion of schedule reliability, and responsiveness/flexibility.

In the container shipping industry, Yuen and Thai (2015) suggested that some service attributes (i.e. speed and ease of claims), and effectiveness of sales team are the main contributors to customer satisfaction, whereas Chen et al. (2017) find that fair price and discount, and personal selling and customer relationship have significant impact on likelihood of customer retention.

In shipping services, Yuen and Thai (2017) identify five latent service quality attributes to measure this construct (i.e. value, transport service, customer service, tangibles and corporate image).

Other studies use standardized scales that adapt as INTSERVQUAL for internal providers' perceptions of quality (Frost, Kumar 2001), and INDSERV in the context of B2B services (Gounaris 2005). SERVQUAL (Parasuraman et al. 1994) merits special mention among service quality measurement proposals as it has been one of the dominant approaches in services research. Various studies have considered this scale for measuring service quality in goods transport (Park et al. 2004; Gounaris 2005; Chen, Lee 2008; Chen et al. 2009), and in logistics operators (Panayides, So 2005) and ports (Ugboma et al. 2004; Ha 2003). Notwithstanding, Chen et al. (2009) do not find support for the use of the SERVQUAL scale in the shipping industry, arguing that both the process perspective proposed by Chen and Chang (2005) and the core service prospect would be adequate approaches for the shipping industry.

\subsubsection{Perceived value in goods transportation}

Perceived value is a determinant variable for motivating purchase decisions of individual and industrial customers, and has been identified as a significant strategic variable for company success (Park et al. 2004; Gil-Saura et al. 2010). Bardauskaite (2014) identified perceived value as one of the customer-focused antecedents of loyalty in the B2B service context. It is therefore essential to consider freight transport service providers as part of the chain whose ultimate aim is to offer value to customers (Robinson 2002).

The literature has paid scanty attention to the study of perceived value in goods transport services but we can establish the conceptual framework for this present study using passenger transport studies. Thus Sirdeshmukh et al. (2002) attempt to further understanding of passenger transport service providers' value generation behaviour while Park et al. (2004) and Petrick (2004) analyse the influence of perceived value and other variables, on decision making, which mainly leads to repurchase intention and recommendation to others. In this area, value has been evaluated with adaptations of the SERV-PERVAL scale (Petrick 2004), while others have used simpler scales, 
focusing on the quality-price relationship (Park et al. 2004) and on timing, effort and global purchase experience (Sirdeshmukh et al. 2002).

As regards the measurement of value in the area of goods transport, Lagoudis et al. (2006) identify the main attributes that contribute to value generation, evaluating the perceptions of companies in various productive sectors that habitually use transport by sea. The measurement is based on the adaptation of the model proposed by Johansson et al. (2007), who propose that to generate value, companies must make efforts to improve product quality and service level while reducing cost and the duration of the cycle (time). Subsequently, Golicic (2007) defines value as the relationship between the "trade-off" between evaluations of benefits obtained through having a relationship and the costs of the inter-company relationship. The empirical study analyses the value of the relationship between dockers and freight forwarders and proposes that relationship value is determined by its strength, which in turn is determined by trust, commitment and dependency.

In view of these contributions, and in the hypercompetitive environment of the freight transport service industry, the analysis of perceived value as a trade-off can be crucial to understand freight forwarder satisfaction and loyalty.

\subsection{Consequences of satisfaction: loyalty in goods transport}

Building customer loyalty is of critical importance since it can act as a stable source of competitive advantage as well as a barrier to the competition in goods transport. Loyalty as a dependent variable is the end consequence of the relationship as it is considered to have the closest connection to company profitability (Kumar et al. 2013; Bardauskaite 2014), and a goal in relationship marketing. Nevertheless, in spite of the importance attributed to loyalty, in contrast to the manifold contributions in the $\mathrm{B} 2 \mathrm{C}$ context, research interest about this variable in the $\mathrm{B} 2 \mathrm{~B}$ setting has been rather limited both in content and in scope (Watson et al. 2015). Therefore, specific research is required on the drivers of customer loyalty in the context of business-tobusiness relations (Russo et al. 2016).

Loyalty has generally been conceived from two different approaches (Jang, Kim 2012), i.e. as a behavioural variable in which the customer has acquired a commitment to repeat purchase, and as an affective component, pointing to the importance of feelings (Kumar et al. 2013). These two perspectives are often combined in the services literature. From this perspective Butcher et al. (2001) identified four dimensions that combine to form services loyalty:

- resistance to change;

- identification with the service;

- particular preference for the service provider;

- positive word-of-mouth.

The literature contains little on loyalty in the goods transport environment. Cunningham and Kettlewood (1976) consider the difference between loyalty to the mode of goods transport and loyalty to the specific company acting as the transport services provider, determining nine loyalty-generating elements that can be grouped in four dimensions: economic factors, organisational factors, past experiences and simplification of the work. Subsequently, in a study aimed at identifying the determinants of loyalty to international logistics operators, Chen and Lee (2008) consider satisfaction, service quality and switching costs as antecedents of loyalty.

As regards the measurement of loyalty, most works in the field of goods or passenger transport consider repurchase intentions and recommendation to other people or word-of-mouth as expressions of loyalty (Sirdeshmukh et al. 2002; Park et al. 2004; Petrick 2004). To these factors, Chen and Lee (2008) add price sensitivity, in the sense that the more sensitive users are to price variations, the less loyal they are to the transport service.

Focusing on maritime transport, Jang and Kim (2012) propose a conceptual model where shipper loyalty (attitudinal and behavioural) is influenced by switching barriers (switching cost, interpersonal relationship and attractiveness of alternative), and relationship quality viewed as a higher-order construct composed of three sub-constructs: satisfaction; trust; commitment.

Thus, understanding loyalty in our research context requires bearing in mind the interrelation between quality, perceived value and satisfaction as their determinants.

\section{Proposed model and hypotheses}

The present research aims at going deeper into the study of satisfaction and loyalty of freight forwarders to their main transport providers. To achieve this objective, firstly a research question is proposed that seeks to establish whether there are differences between modes of transport used for goods transport based on freight forwarders' perceptions in each of the study constructs and secondly, a set of research hypotheses found in the previous literature review are proposed that describe a causal model that emerges from the relationships between service quality, perceived value, satisfaction and loyalty of freight forwarders to freight transport service providers.

Flodén et al. (2017) identify the main factors affecting transport service choice, being the most cited cost, transport quality, reliability, and transport time. Bergantino and Bolis (2008) identify service frequency and transit time as the most influential variables in the transport mode decision when comparing lorry transport and Short Sea Shipping. Evers and Johnson (2000) point to the connection between perceived service quality of each transport mode and companies' use intention. Other works research the differences in perceptions of service quality for each mode of transport and their influence on companies' mode of transport decision (Ludvigsen 1999). Furthermore, Cook et al. (1999) point out that satisfaction with road transport is generally greater than with the other studied modes. Taking into account the above contributions and extrapolating them to the context of our research (i.e. Spanish freight forwarders) therefore we posit: 
H1: Evaluation of service quality (H1a), perceived value $(\mathrm{H} 1 \mathrm{~b})$, satisfaction $(\mathrm{H} 1 \mathrm{c})$ and loyalty $(\mathrm{H} 1 \mathrm{~d})$ of Spanish freight forwarders differs significantly between the studied modes of transport.

The relationships between perceived quality, perceived value and satisfaction have been widely studied (e.g. Juga et al. 2012; Park et al. 2004). In B2C transport literature there are several evidences supporting these relations (Mahmud et al. 2013). In the logistics sphere many studies provide evidence that these relationships are maintained in the context of logistics services (Daugherty 2011), and similarly in goods transport (Yuen, Thai, 2015, 2017; Chang, Thai 2016; Chen et al. 2017; Lobo 2010; Evers, Johnson 2000). Therefore:

H2: Service quality has a positive significant effect on perceived value in Spanish freight forwarders.

H3: Service quality has a positive significant effect on satisfaction in Spanish freight forwarders.

H4: Perceived value has a positive significant effect on satisfaction in Spanish freight forwarders.

Furthermore, there is a consensus in the literature that when global customer satisfaction increases, loyalty to the service provider must increase. This relationship has been also tested in the logistics services environment (Daugherty 2011; Gil-Saura et al. 2010). In goods transport, Evers and Johnson (2000) analyse the influence of dockers' satisfaction on intermodal transport services (rail-road) re-use intentions. Chang and Thai (2016) state that port service quality has a direct and positive impact on both customer satisfaction and customer loyalty; and customer satisfaction has a direct and positive impact on customer loyalty. Therefore we posit the final hypothesis:

H5: Satisfaction has a significant positive effect on Spanish freight forwarders' loyalty.

Based on the above hypotheses, the causal model is specified, considering service quality and perceived value as antecedents of satisfaction and loyalty as the main consequence.

\section{Method}

The theoretical review and the hypotheses formed the basis for an empirical investigation to test the hypotheses. Personal interviews were conducted with 205 managers or high level employees in freight forwarding companies to ask about their perceptions of the service provided by their main transport provider. This procedure is used in previous studies (e.g. Yuen, Thai 2017).

The point of departure of the data collection was the census of freight forwarders in Spain, that includes 558 companies. After having contacted all these companies, the response rate was $37 \%$. We checked that the companies included in the sample complied with two criteria: firstly, maintaining the proportion of companies located in geographical areas with the greatest concentration of freight forwarders in Spain in order to guarantee the sample representativeness, and secondly, according to the mode of transport of the main freight transport service provider, maintaining participation quotas for each mode of transport in the total goods transported in Spain. Following these selection criteria, we expected to obtain a representative sample both in terms of its location and main transport mode.

The questionnaire was designed on the basis of a literature review. Thus service quality was evaluated from the perspective of the five dimension SERVQUAL, but following Cronin and Taylor (1992), only performance scores are retained. Furthermore, perceived value was measured on the scale proposed by Park et al. (2004), also applied by Chen et al. (2009), and specifically designed for the goods transport environment. Three items were added to this scale from a multidimensional value scale developed by Al-Sabbahy et al. (2004) and represent the value dimension of the transaction. The satisfaction scale is an adaptation of the measurement of global satisfaction (3 items) used by O'Loughlin and Coenders (2004). Finally, loyalty is understood from a multidimensional perspective, therefore a scale is developed that retains the following contributions:

- for behavioural intentions a scale is generated that combines the approaches of Chen and Lee (2008) and Sirdeshmukh et al. (2002);

- to evaluate word-of-mouth, the proposal from Lam et al. (2004);

- Chen and Lee's (2008) scale that retains information on price sensitivity.

In all cases the items were measured on a 5-point Likert scale. The questionnaire is completed with a set of company and interviewee classification variables to provide a profile of the sample of freight forwarders, shown in Table 1.

Table 1. Sample description details

\begin{tabular}{|c|c|c|}
\hline Variable & Number & $\%$ \\
\hline \multicolumn{3}{|c|}{ Region } \\
\hline Valencian Region & 48 & 23.4 \\
\hline Catalonia & 49 & 23.9 \\
\hline Madrid & 42 & 20.5 \\
\hline Basque Country & 27 & 13.2 \\
\hline Andalusia & 4 & 11.7 \\
\hline Galicia & 9 & 4.4 \\
\hline Aragon & 6 & 2.9 \\
\hline \multicolumn{3}{|c|}{ Main mode of transport } \\
\hline Road & 79 & 38.5 \\
\hline Maritime & 108 & 52.7 \\
\hline Air & 18 & 8.8 \\
\hline \multicolumn{3}{|c|}{ Firm age } \\
\hline up to 10 years old & 38 & 18.5 \\
\hline $11 \ldots 20$ years old & 62 & 30.2 \\
\hline more than 20 years old & 105 & 51.2 \\
\hline \multicolumn{3}{|c|}{ Number of employees in Spain } \\
\hline up to 25 & 115 & 56.1 \\
\hline $26 \ldots 100$ & 48 & 23.5 \\
\hline $101 \ldots 500$ & 33 & 16.1 \\
\hline more than 500 & 9 & 4.3 \\
\hline
\end{tabular}




\section{Results}

\subsection{Descriptive and comparative analysis of transport modes}

Based on the data collected with the questionnaire (see Appendix), Table 2 shows the average scores for each of the indicators in the scales for the different study constructs. These data are presented segmenting the sample by transport mode of the transport company that each freight forwarder evaluated, to enable comparison of transport mode. The ANOVA identifies the indicators with statistically different values among the three transport modes thereby providing information on the elements that generate differences in the evaluation of the service. Tukey's post-hoc multiple comparison test is used for comparing different modes.

Analysis of the mean differences in the service quality scale shows that of the 21 scale items, 12 show significant differences between the three modes, suggesting that in general, freight forwarders' perceptions of the service quality delivered by transport companies vary according to transport mode, thereby confirming $\mathrm{H} 1$. Of the 12 differences between modes, 9 of them occur between road and sea transport, the remaining three between road and air transport and no perceived quality item has statistically different scores between sea and air transport. Reliability, reactivity and empathy concentrate the greatest differences in perceived service between the different transport modes, followed by guarantee, which only shows differences in 2 indicators and finally the tangibility dimension that only shows that the evaluation of vehicle cleanness in each mode is different.

Regarding perceived value, average values for all road transport indicators are higher, followed by sea transport and finally, air transport, thereby suggesting that road transport offers freight forwarding companies a higher service level in relation to the price paid. However, ANOVA indicates that freight forwarders' evaluations of the relationship between what they have paid and the level of service received shows no differences associated with transport mode, and so $\mathrm{H} 1 \mathrm{~b}$ is rejected.

Furthermore, of the three indicators in the satisfaction scale, two of them show significant differences between the different modes, in the first item between road and sea transport, in the third item between road and air transport and so freight forwarders come closer to reaching high levels of satisfaction when working with land transport companies. This evidence allows us to conclude that H1c is accepted.

Mean scores and ANOVA show no significant differences between the transport modes in any of the variables in the loyalty scale, as the variations in the means associated to the different transport modes for all the indicators are not statistically significant, therefore H1d is rejected.

\subsection{Estimation of the proposed causal model}

\subsubsection{Evaluation of measurement model}

Partial Least Squares (PLS) methodology was used to validate the measurement instrument and estimate the causal model. The results allow to confirm the convergent validity through the analysis of the loadings, cross-loadings of each indicator and the Average Variance Extracted (AVE) of each latent variable (Fornell, Larcker 1981).

Reliability, measured with Cronbach's $\alpha$ and the composed reliability index, has the minimum required values, respectively (Table 3). Significance of the factor loadings was determined by bootstrapping.

The discriminant validity was confirmed, as each square root of AVE was higher than the correlations with other constructs, according to the Fornell-Larcker criterion (Fornell, Larcker 1981). Furthermore, the value for heterotrait-monotrait ratios is below the threshold of 0.90 in all cases, according to Gold et al. (2001). The results obtained allow to confirm the discriminant validity of the measurement instrument.

As a result of this validation procedure, the indicators for measuring the reliability and guarantee dimensions were eliminated from the perceived quality scale because of problems of convergent validity. The perceived value and satisfaction scales kept all their indicators. Furthermore, the loyalty scale, which originally collected positive word-of-mouth, sensitivity to price and intention to continue using the service, only retains the first two as all the indicators that evaluated intention to continue using the service showed low values in factor loadings. The above may be an indication that the instrument designed to evaluate companies' behavioural intention in the specific study environment needs revising in future works.

\subsubsection{Testing the structural model}

Based on the results from the validation of the measurement instrument, the following step was to estimate the structural model. All the values of the $R^{2}$ were above the minimum threshold of 0.1 (Falk, Miller 1992) and Q2 indicators of all the latent variables obtained by Blindfolding suggests that the model has predictive validity as they are all positive (Table 4).

Model estimation results and analysis of the significance of the relationships through bootstrapping (Hair et al. 2017) confirm a positive relationship between service quality and satisfaction (H3: $\beta=0.2282, p<0.01)$, as well as between service quality and perceived value $(\mathrm{H} 2$ : $\beta=0.3677, p<0.01)$ and between perceived value and satisfaction (H4: $\beta=0.3781, p<0.01$ ). Finally, the model estimation data confirms the hypothesis of an association between freight forwarder satisfaction and increased loyalty to the transport company (H5: $\beta=0.5409, p<0.05$ ). 
Table 2. Mean values for transport modes

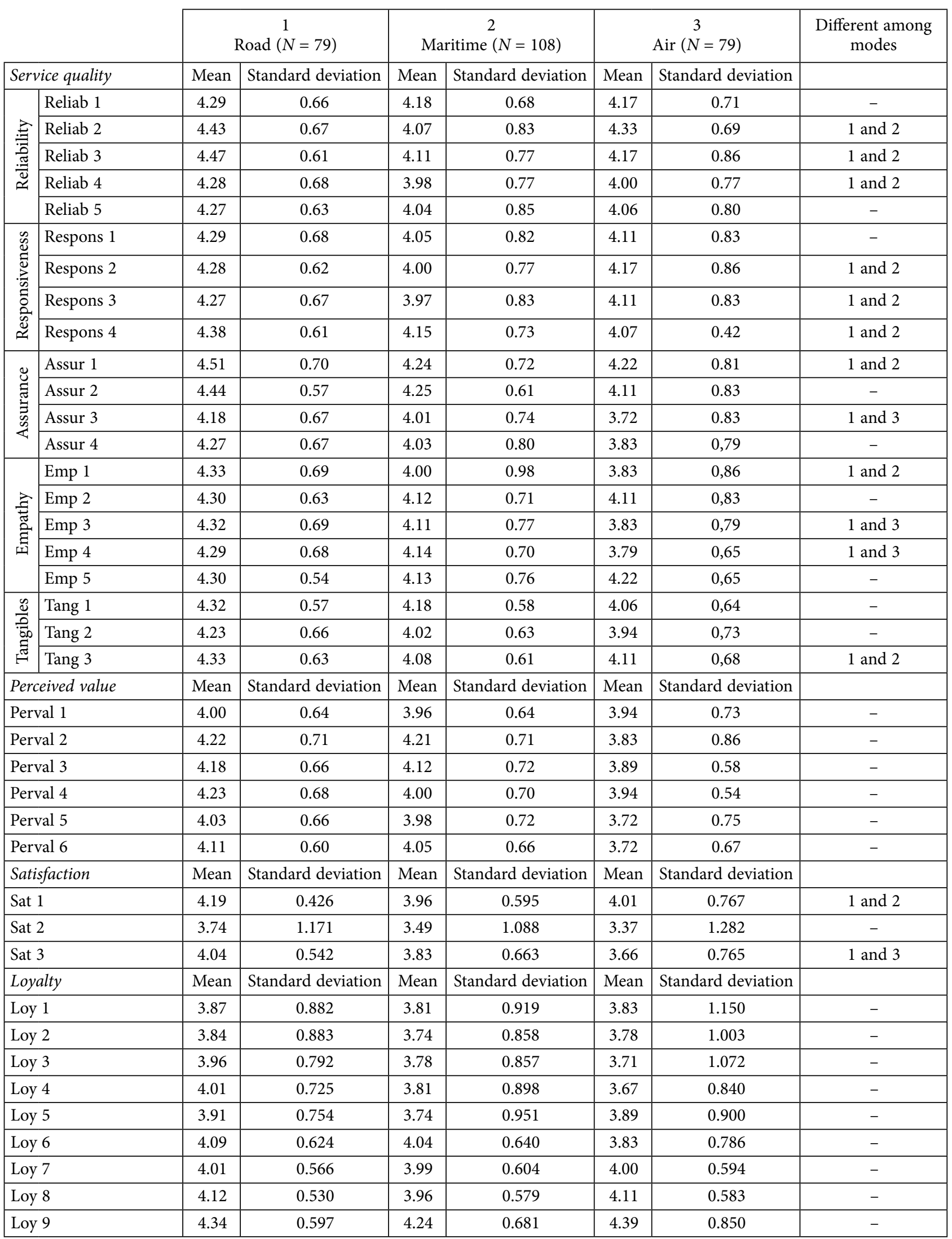


Table 3. Validation of measurement instrument: reliability and convergent validity

\begin{tabular}{|c|c|c|c|c|c|c|c|}
\hline \multicolumn{2}{|c|}{ Factor } & Indicator & Loading & $t$ & Cronbach $\alpha$ & Composite reliability & AVE \\
\hline \multirow{20}{*}{ Service quality } & GLOBAL & SQGLOBAL & 1.0000 & - & - & - & - \\
\hline & \multirow{4}{*}{ Reliability } & Reliab 1 & $0.8324^{\star *}$ & 29.4928 & \multirow{4}{*}{0.8568} & \multirow{4}{*}{0.9026} & \multirow{4}{*}{0.6985} \\
\hline & & Reliab 2 & $0.8105^{\star *}$ & 23.6220 & & & \\
\hline & & Reliab 3 & $0.8552^{\star *}$ & 36.4726 & & & \\
\hline & & Reliab 4 & $0.8443^{\star *}$ & 35.1754 & & & \\
\hline & \multirow{4}{*}{ Responsiveness } & Respons 1 & $0.8112^{\star *}$ & 20.9912 & \multirow{4}{*}{0.8049} & \multirow{4}{*}{0.8711} & \multirow{4}{*}{0.6289} \\
\hline & & Respons 2 & $0.7623^{\star *}$ & 17.5184 & & & \\
\hline & & Respons 3 & $0.8503^{* *}$ & 31.1832 & & & \\
\hline & & Respons 4 & $0.7441^{\star *}$ & 19.8428 & & & \\
\hline & \multirow{3}{*}{ Tangibility } & Tang 1 & $0.7308^{\star \star}$ & 14.5524 & \multirow{3}{*}{0.7397} & \multirow{3}{*}{0.8529} & \multirow{3}{*}{0.6602} \\
\hline & & Tang 2 & $0.8378^{\star \star}$ & 31.7788 & & & \\
\hline & & Tang 3 & $0.8630^{\star *}$ & 39.0454 & & & \\
\hline & \multirow{5}{*}{ Empathy } & Emp 1 & $0.8268^{* *}$ & 33.0681 & \multirow{5}{*}{0.8389} & \multirow{5}{*}{0.8858} & \multirow{5}{*}{0.6083} \\
\hline & & Emp 2 & $0.7547^{\star *}$ & 21.8116 & & & \\
\hline & & Emp 3 & $0.7724^{\star \star}$ & 22.0582 & & & \\
\hline & & Emp 4 & $0.7696^{\star *}$ & 27.7775 & & & \\
\hline & & Emp 5 & $0.7743^{\star *}$ & 18.5929 & & & \\
\hline & \multirow{3}{*}{ Assurance } & Assur 1 & $0.8051^{\star *}$ & 27.1881 & \multirow{3}{*}{0.7414} & \multirow{3}{*}{0.8528} & \multirow{3}{*}{0.6588} \\
\hline & & Assur 2 & $0.8017^{\star \star}$ & 22.7629 & & & \\
\hline & & Assur 3 & $0.8280^{\star *}$ & 26.3679 & & & \\
\hline \multirow{6}{*}{\multicolumn{2}{|c|}{ Perceived value }} & Perval 1 & $0.7496^{\star \star}$ & 15.9191 & \multirow{6}{*}{0.8106} & \multirow{6}{*}{0.8637} & \multirow{6}{*}{0.5139} \\
\hline & & Perval 2 & $0.7833^{\star *}$ & 15.4163 & & & \\
\hline & & Perval 3 & $0.7206^{* *}$ & 16.5482 & & & \\
\hline & & Perval 4 & $0.7136^{\star *}$ & 19.3160 & & & \\
\hline & & Perval 5 & $0.7101^{\star *}$ & 18.0042 & & & \\
\hline & & Perval 6 & $0.7224^{\star \star}$ & 21.8922 & & & \\
\hline \multirow{3}{*}{\multicolumn{2}{|c|}{ Satisfaction }} & Sat 3 & $0.7523^{\star \star}$ & 12.4541 & \multirow{3}{*}{0.7148} & & \\
\hline & & Sat 2 & $0.7105^{\star *}$ & 13.0999 & & 0.8424 & 0.6437 \\
\hline & & Sat 1 & $0.9275^{\star *}$ & 74.7614 & & & \\
\hline & & Loy 1 & $0.8552^{\star \star}$ & 42.5191 & & & \\
\hline & & Loy 2 & $0.7926^{\star *}$ & 17.0421 & & & \\
\hline Loyalty & & Loy 3 & $0.8293^{\star *}$ & 29.7816 & 0.8469 & 0.8911 & 0.6218 \\
\hline & & Loy 4 & $0.7209^{\star *}$ & 17.5407 & & & \\
\hline & & Loy 5 & $0.7361^{\star *}$ & 20.8651 & & & \\
\hline
\end{tabular}

Notes: ${ }^{*} p<0.05 ;{ }^{* *} p<0.01$.

Table 4. Results of hypotheses test

\begin{tabular}{|l|l|c|c|c|}
\cline { 2 - 5 } \multicolumn{1}{c|}{} & \multicolumn{1}{c|}{ Causal relation } & Hypothesis & Standardized $\beta$ coefficient & $t$-bootstrapping \\
\hline H2 & service quality $\rightarrow$ perceived value & supported & $0.3677^{* *}$ & 4.9649 \\
\hline H3 & service quality $\rightarrow$ satisfaction & supported & $0.2282^{\star *}$ & 3.7224 \\
\hline H4 & perceived value $\rightarrow$ satisfaction & supported & $0.3781^{\star *}$ & 6.7043 \\
\hline H5 & satisfaction $\rightarrow$ loyalty & supported & $0.5409^{* *}$ & 9.7319 \\
\hline
\end{tabular}

Notes:

- perceived value: $R^{2}=0.1352, \mathrm{Q} 2=0.0559$;

- satisfaction: $R^{2}=0.2585, \mathrm{Q} 2=0.1436$;

- loyalty: $R^{2}=0.2926, \mathrm{Q} 2=0.1680$;

$-{ }^{\star} p<0.05,{ }^{* *} p<0.01$. 


\section{Conclusions and managerial implications}

The main objective of this work is to analyse the nature of satisfaction and loyalty in the context of goods transport and to determine the relationships between variables, which the literature in different areas of study points to as the antecedents. To analyse these relations, freight transport services are the selected setting, in view of its high strategic value and its priority role in research in Europe.

From a conceptual point of view, the theoretical review indicates much academic interest in these topics in recent decades. However, research is still not totally conclusive and application of the theory to the area of logistics services and specifically goods transport is still in progress. The proposal and estimation of the theoretical model that presents the causal relationships between the different constructs evaluated in this study has confirmed that service quality and perceived value are antecedent variables of satisfaction. Similarly, quality influences satisfaction through perceived value and therefore suggests that service quality dimensions are key elements, which transport services providers need to address to identify lines of action and develop strategies to increase perceived value and customer satisfaction. As regards the relationship between satisfaction and its consequences, a direct connection is confirmed between freight forwarders' levels of satisfaction and attitudinal loyalty to their main transport provider, expressed in their intention to generate positive word-of-mouth and in a low sensitivity to variations in the cost of the transport service.

Moreover, comparison of the scores for each indicator of the study constructs between the different modes shows that freight forwarders work mainly with road transport companies as they show higher levels of service quality, perceived value, satisfaction and loyalty than the other two modes.

The above conclusions provide a set of managerial implications for companies involved in the transport of goods. In this sense, results allow to conclude that investment aimed at increasing quality in the transport service that freight forwarders perceive will enable a transport company to differentiate itself and strengthen the pillars on which it builds stable long-term relationships with them, thereby increasing the perception of value contributed by the company in each transport operation and thus increase satisfaction. As customer loyalty is one of the main goals of companies seeking long-term profitability and sustainability, transport companies need to develop strategically designed actions to increase customer satisfaction, activities, which may involve improving each component of service quality.

Finally, the present study is not free from limitations whereas allows to suggest future research lines. The main limitation of this study is the need to review the methodology for measuring loyalty, especially the behavioural intention dimension, which was eliminated from the measurement instrument because of poor reliability and validity indicators. We therefore suggest exploring differ- ent approaches for evaluating this construct that are better suited to the specific study environment. As regards future research lines, firstly, more in-depth study could be made of the quality-value-satisfaction-loyalty chain between companies participating in goods transport. We also propose a deeper study of the differences in service indicators between the different transport modes in order to find factors that at mode level will help to improve the service. Finally, it would be advisable to evaluate intercompany relationships in this context by measuring the constructs from other approaches and thus obtain more empirical evidence to further knowledge in this area.

\section{Acknowledgements}

This research has been developed in the framework of the project ECO2016-76553-R financed by Spanish Ministry of Economy and Competitiveness.

\section{References}

Al-Sabbahy, H. Z.; Ekinci, Y.; Riley, M. 2004. An investigation of perceived value dimensions: implications for hospitality research, Journal of Travel Research 42(3): 226-234. https://doi.org/10.1177/0047287503258841

Bardauskaite, I. 2014. Loyalty in the business-to-business service context: a literature review and proposed framework, Journal of Relationship Marketing 13(1): 28-69.

https://doi.org/10.1080/15332667.2014.882628

Bergantino, A. S.; Bolis, S. 2008. Monetary values of transport service attributes: land versus maritime ro-ro transport. An application using adaptive stated preferences, Maritime Policy \& Management: The Flagship Journal of International Shipping and Port Research 35(2): 159-174.

https://doi.org/10.1080/03088830801956821

Bucklin, R. E. 2015. An introduction to the special issue, Journal of Retailing 91(4): 543-545.

https://doi.org/10.1016/j.jretai.2015.03.004

Butcher, K.; Sparks, B.; O'Callaghan, F. 2001. Evaluative and relational influences on service loyalty, International Journal of Service Industry Management 12(4): 310-327.

https://doi.org/10.1108/09564230110405253

Chang, C.-H.; Thai, V. V. 2016. Do port security quality and service quality influence customer satisfaction and loyalty?, Maritime Policy \& Management: the Flagship Journal of International Shipping and Port Research 43(6): 720-736. https://doi.org/10.1080/03088839.2016.1151086

Chen, C.-H.; Lee, H.-Y. 2008. Empirical analysis of the customer loyalty problem in the international logistics market, WSEAS Transactions on Business and Economics 5(4): 113-123.

Chen, F.-Y.; Chang, Y.-H. 2005. Examining airline service quality from a process perspective, Journal of Air Transport Management 11(2): 79-87.

https://doi.org/10.1016/j.jairtraman.2004.09.002

Chen, K.-K.; Chang, C.-T.; Lai, C.-S. 2009. Service quality gaps of business customers in the shipping industry, Transportation Research Part E: Logistics and Transportation Review 45(1): 222-237. https://doi.org/10.1016/j.tre.2008.02.005

Chen, K. K.; Chiu, R.-H.; Chang, C.-T. 2017. Using beta regression to explore the relationship between service attributes and likelihood of customer retention for the container shipping 
industry, Transportation Research Part E: Logistics and Transportation Review 104: 1-16.

https://doi.org/10.1016/j.tre.2017.04.015

Cook, P. D.; Das, S.; Aeppli, A.; Martland, C. 1999. Key factors in road-rail mode choice in India: applying the logistics cost approach, in WSC'99. 1999 Winter Simulation Conference Proceedings "Simulation - a Bridge to the Future", 5-8 December 1999, Phoenix, AZ, US, 2: 1280-1286.

https://doi.org/10.1109/WSC.1999.816854

Cronin, J. J.; Taylor, S. A. 1992. Measuring service quality: a reexamination and extension, Journal of Marketing 56(3): 55-68. https://doi.org/10.2307/1252296

Cunningham, M. T.; Kettlewood, K. 1976. Source loyalty in the freight transport market, European Journal of Marketing 10(1): 60-79. https://doi.org/10.1108/EUM0000000005038

Daugherty, P. J. 2011. Review of logistics and supply chain relationship literature and suggested research agenda, International Journal of Physical Distribution \& Logistics Management 41(1): 16-31. https://doi.org/10.1108/09600031111101402

Ding, J.-F.; Tsai, P.-P. 2012. Evaluating quality improvement of service recovery for ocean freight forwarders in Taiwan, Information Technology Journal 11(11): 1579-1587.

https://doi.org/10.3923/itj.2012.1579.1587

Durvasula, S.; Lysonski, S.; Mehta, S. C. 2000. Business-to-business marketing service recovery and customer satisfaction issues with ocean shipping lines, European Journal of Marketing 34(3/4): 433-452.

https://doi.org/10.1108/03090560010311957

Evers, P. T.; Johnson, C. J. 2000. Performance perceptions, satisfaction, and intention: the intermodal shipper's perspective, Transportation Journal 40(2): 27-39.

Falk, R. F.; Miller, N. B. 1992. A Primer for Soft Modeling. University of Akron Press. 103 p.

Flodén, J.; Bärthel, F.; Sorkina, E. 2017. Transport buyers choice of transport service - a literature review of empirical results, Research in Transportation Business \& Management 23: 35-45. https://doi.org/10.1016/j.rtbm.2017.02.001

Fornell, C.; Larcker, D. F. 1981. Evaluating structural equation models with unobservable variables and measurement error, Journal of Marketing Research 18(1): 39-50. https://doi.org/10.2307/3151312

Frost, F. A.; Kumar, M. 2001. Service quality between internal customers and internal suppliers in an international airline, International Journal of Quality \& Reliability Management 18(4): 371-386. https://doi.org/10.1108/02656710110386996

Gil-Saura, I.; Servera-Francés, D.; Fuentes-Blasco, M. 2010. Antecedents and consequences of logistics value: and empirical investigation in the Spanish market, Industrial Marketing Management 39(3): 493-506.

https://doi.org/10.1016/j.indmarman.2008.11.007

Gold, A. H.; Malhotra, A.; Segars, A. H. 2001. Knowledge management: an organizational capabilities perspective, Journal of Management Information Systems 18(1): 185-214. https://doi.org/10.1080/07421222.2001.11045669

Golicic, S. L. 2007. A comparison of shipper and carrier relationship strength, International Journal of Physical Distribution \& Logistics Management 37(9): 719-739.

https://doi.org/10.1108/09600030710840831

Gounaris, S. 2005. Measuring service quality in B2B services: an evaluation of the SERVQUAL scale vis-à-vis the INDSERV scale, Journal of Services Marketing 19(6): 421-435. https://doi.org/10.1108/08876040510620193
Ha, M.-S. 2003. A comparison of service quality at major container ports: implications for Korean ports, Journal of Transport Geography 11(2): 131-137.

https://doi.org/10.1016/S0966-6923(02)00069-8

Hair, J. F.; Hult, G. T. M.; Ringle, C.; Sarstedt, M. 2017. A Primer on Partial Least Squares Structural Equation Modeling (PLSSEM). Sage Publications, Inc. 384 p.

Harper, D. V.; Evers, P. T. 1993. Competitive issues in intermodal railroad-truck service, Transportation Journal 32(3): 31-45.

Huang, P.-L.; Lee, B. C. Y.; Chen, C.-C. 2017. The influence of service quality on customer satisfaction and loyalty in B2B technology service industry, Total Quality Management \& Business Excellence, 1-17. https://doi.org/10.1080/14783363.2017.1372184

Huang, S. T.; Bulut, E.; Duru, O. 2015. Service quality assessment in liner shipping industry: an empirical study on Asian shipping case, International Journal of Shipping and Transport Logistics 7(2): 221-242.

http://doi.org/10.1504/IJSTL.2015.067852

Jang, H. M.; Kim, S. Y. 2012. Customer loyalty and logistics service performance in maritime transport: a literature review and conceptual model, Journal of Navigation and Port Research 36(9): 753-761.

https://doi.org/10.5394/KINPR.2012.36.9.753

Johansson, H. J.; McHugh, P.; Pendlebury, A. J.; Wheeler, W. A. 2007. Business Process Reengineering: Breakpoint Strategies for Market Dominance. Wiley. 256 p.

Juga, J.; Juntunen, J.; Juntunen, M. 2012. Impact of service quality, image and relational aspects on satisfaction and loyalty in logistics outsourcing relationships, International Journal of Shipping and Transport Logistics 4(1): 17-28. https://doi.org/10.1504/IJSTL.2012.044133

Kersten, W.; Koch, J. 2010. The effect of quality management on the service quality and business success of logistics service providers, International Journal of Quality \& Reliability Management 27(2): 185-200. https://doi.org/10.1108/02656711011014302

Kumar, V. Pozza, I. D.; Ganesh, J. 2013. Revisiting the satisfaction-loyalty relationship: empirical generalizations and directions for future research, Journal of Retailing 89(3): 246-262. https://doi.org/10.1016/j.jretai.2013.02.001

Lagoudis, I. N.; Lalwani, C. S.; Naim, M. M. 2006. Ranking of factors contributing to higher performance in the ocean transportation industry: a multi-attribute utility theory approach, Maritime Policy \& Management: The Flagship Journal of International Shipping and Port Research 33(4): 345-369. https://doi.org/10.1080/03088830600895568

Lam, S. Y.; Shankar, V.; Erramilli, M. K.; Murthy, B. 2004. Customer value, satisfaction, loyalty, and switching costs: an illustration from a business-to-business service context, Journal of the Academy of Marketing Science 32(3): 293-311. https://doi.org/10.1177/0092070304263330

Lobo, A. 2010. Assessing the service quality of container shipping lines in the international supply chain network - shippers' perspective, International Journal of Value Chain Management 4(3): 256-266. https://doi.org/10.1504/IJVCM.2010.033615

Lu, C.-S. 2007. Evaluating key resources and capabilities for liner shipping services, Transport Reviews 27(3): 285-310. https://doi.org/10.1080/01441640600984015

Lu, C.-S. 2003. The impact of carrier service attributes on shipper-carrier partnering relationships: a shipper's perspective, Transportation Research Part E: Logistics and Transportation Review 39(5): 399-415. https://doi.org/10.1016/S1366-5545(03)00015-2 
Ludvigsen, J. 1999. Freight transport supply and demand conditions in the Nordic countries: recent evidence, Transportation Journal 39(2): 31-54.

Mahmud, A.; Jusoff, K.; Hadijah, S. 2013. The effect of service quality and price on satisfaction and loyalty of customer of commercial flight service industry, World Applied Sciences Journal 23(3): 354-359.

Naumann, E.; Williams, P.; Khan, M. S. 2009. Customer satisfaction and loyalty in $\mathrm{B} 2 \mathrm{~B}$ services: directions for future research, The Marketing Review 9(4): 319-333. https://doi.org/10.1362/146934709X479908

O’Loughlin, C.; Coenders, G. 2004. Estimation of the European customer satisfaction index: maximum likelihood versus partial least squares. Application to postal services, Total Quality Management \& Business Excellence 15(9-10): 1231-1255. https://doi.org/10.1080/1478336042000255604

Panayides, P. M.; So, M. 2005. The impact of integrated logistics relationships on third-party logistics service quality and performance, Maritime Economics \& Logistics 7(1): 36-55. https://doi.org/10.1057/palgrave.mel.9100123

Parasuraman, A.; Zeithaml, V. A.; Berry, L. L. 1994. Reassessment of expectations as a comparison standard in measuring service quality: implications for further research, Journal of Marketing 58(1): 111-124. https://doi.org/10.2307/1252255

Park, J.-W.; Robertson, R.; Wu, C.-L. 2004. The effect of airline service quality on passengers' behavioural intentions: a Korean case study, Journal of Air Transport Management 10(6): 435-439. https://doi.org/10.1016/j.jairtraman.2004.06.001

Petrick, J. F. 2004. The roles of quality, value, and satisfaction in predicting cruise passengers' behavioral intentions, Journal of Travel Research 42(4): 397-407.

https://doi.org/10.1177/0047287504263037

Robinson, R. 2002. Ports as elements in value-driven chain systems: the new paradigm, Maritime Policy \& Management: the Flagship Journal of International Shipping and Port Research 29(3): 241-255. https://doi.org/10.1080/03088830210132623

Russo, I.; Confente, I.; Gligor, D. M.; Autry, C. W. 2016. To be or not to be (loyal): is there a recipe for customer loyalty in the B2B context?, Journal of Business Research 69(2): 888-896. https://doi.org/10.1016/j.jbusres.2015.07.002

Singh, H.; Garg, R. K.; Sachdeva, A. 2018. Supply chain collaboration: a state-of-the-art literature review, Uncertain Supply Chain Management 6(2): 149-180.

https://doi.org/10.5267/j.uscm.2017.8.002

Sirdeshmukh, D.; Singh, J.; Sabol, B. 2002. Consumer trust, value, and loyalty in relational exchanges, Journal of Marketing 66(1): 15-37. https://doi.org/10.1509/jmkg.66.1.15.18449

Solakivi, T.; Ojala, L. 2017. Determinants of carrier selection: updating the survey methodology into the $21^{\text {st }}$ century, Transportation Research Procedia 25: 511-530. https://doi.org/10.1016/j.trpro.2017.05.433

Song, D.-P.; Li, D.; Drake, P. 2015. Multi-objective optimization for planning liner shipping service with uncertain port times, Transportation Research Part E: Logistics and Transportation Review 84: 1-22. https://doi.org/10.1016/j.tre.2015.10.001

Thai, V. 2008. Service quality in maritime transport: conceptual model and empirical evidence, Asia Pacific Journal of Marketing and Logistics 20(4): 493-518. https://doi.org/10.1108/13555850810909777

Ugboma, C.; Ibe, C.; Ogwude, I. C. 2004. Service quality measurements in ports of a developing economy: Nigerian ports survey, Managing Service Quality: An International Journal 14(6): 487-495. https://doi.org/10.1108/09604520410569829
Ugboma, C.; Ogwude, I. C.; Ugboma, O.; Nnadi, K. 2007. Service quality and satisfaction measurements in Nigerian ports: an exploration, Maritime Policy \& Management: the Flagship Journal of International Shipping and Port Research 34(4): 331-346. https://doi.org/10.1080/03088830701539073

Watson, G. F.; Beck, J. T.; Henderson, C. M.; Palmatier, R. W. 2015. Building, measuring, and profiting from customer loyalty, Journal of the Academy of Marketing Science 43(6): 790-825. https://doi.org/10.1007/s11747-015-0439-4

Whyte, J. L. 1993. The freight transport market: buyer-seller relationships and selection criteria, International Journal of Physical Distribution \& Logistics Management 23(3): 29-37. https://doi.org/10.1108/09600039310039179

Wong, P. C.; Yan, H.; Bamford, C. 2008. Evaluation of factors for carrier selection in the China Pearl River delta, Maritime Policy \& Management: The Flagship Journal of International Shipping and Port Research 35(1): 27-52. https://doi.org/10.1080/03088830701848854

Yuen, K. F.; Thai, V. V. 2015. Service quality and customer satisfaction in liner shipping, International Journal of Quality and Service Sciences 7(2/3): 170-183. https://doi.org/10.1108/IJQSS-02-2015-0024

Yuen, K. F.; Thai, V. 2017. Service quality appraisal: a study of interactions, Total Quality Management \& Business Excellence 28(7-8): 730-745. https://doi.org/10.1080/14783363.2015.1114881 


\section{APPENDIX}

\section{Questionnaire}

\begin{tabular}{|c|c|c|c|}
\hline \multicolumn{3}{|c|}{ Latent variable } & Items \\
\hline \multirow{21}{*}{$\begin{array}{l}\text { Service } \\
\text { quality }\end{array}$} & \multirow{5}{*}{ Reliability } & Reliab 1 & Fulfilment of promises \\
\hline & & Reliab 2 & The interest I demand in resolving transport problems \\
\hline & & Reliab 3 & Reliability of the service \\
\hline & & Reliab 4 & Compliance with the promised schedule \\
\hline & & Reliab 5 & Level of errors during transport \\
\hline & \multirow{4}{*}{ Responsive-ness } & Respons 1 & Level of precision in the information on when the shipment will take place \\
\hline & & Respons 2 & Speed of service \\
\hline & & Respons 3 & Willingness of the carrier's employees to help \\
\hline & & Respons 4 & Willingness of the transport company's employees to respond to our requests \\
\hline & \multirow{4}{*}{ Assurance } & Assur 1 & The confidence I have in the transport company's employees \\
\hline & & Assur 2 & The level of safety in the shipping \\
\hline & & Assur 3 & The level of courtesy and service from the employees \\
\hline & & Assur 4 & Employees' level of knowledge to respond to the questions we ask them \\
\hline & \multirow{5}{*}{ Empathy } & Emp 1 & The level of personalised service \\
\hline & & Emp 2 & The degree of adaptation of the carrier's working hours to mine \\
\hline & & Emp 3 & The level of careful attention expected from employees who deal directly with us \\
\hline & & Emp 4 & The intensity of their concern over our interests \\
\hline & & Emp 5 & Understanding of our specific transport needs \\
\hline & \multirow{3}{*}{ Tangibility } & Tang 1 & How modern the transport company's equipment is \\
\hline & & Tang 2 & How attractive the facilities are \\
\hline & & Tang 3 & The level of cleanliness and care for the vehicles \\
\hline \multirow{6}{*}{\multicolumn{2}{|c|}{ Perceived value }} & Perval 1 & $\begin{array}{l}\text { Considering the total price my company pays for this transport service, } \\
\text { I think this company has offered sufficient service }\end{array}$ \\
\hline & & Perval 2 & The total price for the shipment (including loading and unloading), is reasonable \\
\hline & & Perval 3 & My company has received a good quality transport service for a reasonable price \\
\hline & & Perval 4 & $\begin{array}{l}\text { Given the time this company takes with shipments, I consider it is worth the money } \\
\text { we pay for its service }\end{array}$ \\
\hline & & Perval 5 & Compared to what I would like to pay (realistically), the price I pay is adequate \\
\hline & & Perval 6 & This carrier satisfies my specific transport needs at a reasonable price \\
\hline \multirow{3}{*}{\multicolumn{2}{|c|}{ Satisfaction }} & Sat 1 & In general, your company is pleased with the service offered by this carrier \\
\hline & & Sat 2 & The service received from this company has exceeded your expectations \\
\hline & & Sat 3 & The service you have received from this company is very close to ideal \\
\hline \multirow{9}{*}{ Loyalty } & & Loy 1 & I have said positive things to ___ colleagues from other carriers \\
\hline & & Loy 2 & I have recommended ___ to colleagues at carriers who have sought my advice \\
\hline & & Loy 3 & I have encouraged other companies to work with \\
\hline & & Loy 4 & $\begin{array}{l}\text { You are willing to stay with this company even if the prices of the service are increased } \\
\text { to a reasonable level }\end{array}$ \\
\hline & & Loy 5 & $\begin{array}{l}\text { Thinking about the same transport service, you are willing to continue working with } \\
\text { this company, even though its rates are more expensive than others }\end{array}$ \\
\hline & & Loy 6 & In the same situation, you would choose the same carriers \\
\hline & & Loy 7 & Your company would put this carrier among the priority ones to work with \\
\hline & & Loy 8 & I will make more shipments with this company in the near future \\
\hline & & Loy 9 & $\begin{array}{l}\text { What is the likelihood of using this carrier again when you have to make a similar } \\
\text { shipment }\end{array}$ \\
\hline
\end{tabular}

Note: items in italics were eliminated from the questionnaire from the results of the measurement model. 